\title{
Antihypertensive agents: a long way to safe drug prescribing in children
}

\author{
Nida Siddiqi ${ }^{1} \cdot$ Ibrahim F. Shatat ${ }^{2,3,4}$ (B) \\ Received: 31 May 2019 / Revised: 12 July 2019 / Accepted: 23 July 2019 / Published online: 1 November 2019 \\ (C) The Author(s) 2019
}

\begin{abstract}
Recently updated clinical guidelines have highlighted the gaps in our understanding and management of pediatric hypertension. With increased recognition and diagnosis of pediatric hypertension, the use of antihypertensive agents is also likely to increase. Drug selection to treat hypertension in the pediatric patient population remains challenging. This is primarily due to a lack of large, well-designed pediatric safety and efficacy trials, limited understanding of pharmacokinetics in children, and unknown risk of prolonged exposure to antihypertensive therapies. With newer legislation providing financial incentives for conducting clinical trials in children, along with publication of pediatric-focused guidelines, literature available for antihypertensive agents in pediatrics has increased over the last 20 years. The objective of this article is to review the literature for safety and efficacy of commonly prescribed antihypertensive agents in pediatrics. Thus far, the most data to support use in children was found for angiotensin-converting enzyme inhibitors (ACE-I), angiotensin receptor blockers (ARB), and calcium channel blockers (CCB). Several gaps were noted in the literature, particularly for beta blockers, vasodilators, and the long-term safety profile of antihypertensive agents in children. Further clinical trials are needed to guide safe and effective prescribing in the pediatric population.
\end{abstract}

Keywords Antihypertensive agents $\cdot$ Clinical trials $\cdot$ Drug therapy $\cdot$ Hypertension $\cdot$ Pediatric $\cdot$ Safety

\section{Introduction}

Hypertension (HTN) in children and adolescents is defined as an average clinic measured systolic blood pressure (SBP) and/ or diastolic blood pressure (DBP) $\geq 95$ th percentile (on the basis of age, sex, and height percentiles) [1]. Historically, pediatric HTN was considered a secondary phenomenon until proven otherwise. However, recent evidence describes primary HTN as being more likely than secondary HTN among children referred to subspecialty care for evaluation of elevated blood pressure (BP). Furthermore, the prevalence of HTN in children has been rising alongside the prevalence of obesity and increased awareness and screening among pediatricians

Ibrahim F. Shatat

ishatat@sidra.org

Department of Pharmacy, Sidra Medicine, Doha, Qatar

2 Pediatric Nephrology and Hypertension, Sidra Medicine, HB. 7A. 106A, PO Box 26999, Doha, Qatar

3 Weill Cornell College of Medicine-Qatar, Ar-Rayyan, Qatar

4 Medical University of South Carolina, Charleston, SC, USA and general practitioners. It is estimated that $3.5 \%$ of children and adolescents suffer from HTN, with prevalence as high as $25 \%$ in obese and overweight adolescents [2, 3].

In children and adolescents diagnosed with HTN, the treatment goal with non-pharmacologic and pharmacologic therapy should be a reduction in SBP and DBP to $<90$ th percentile or $<130 / 80 \mathrm{~mm} \mathrm{Hg}$, whichever is lower [1]. It is widely acceptable and recommended that lifestyle modifications should be the first-line management approach for HTN in children and adolescents. Antihypertensive medications are reserved for children with hypertensive urgencies and emergencies, evidence of target organ damage, co-existent comorbidities, and failed first-line management [1].

Clinical practice guidelines for screening and management of high BP in children and adolescents [1] recommend a stepwise therapeutic approach, starting with a single medication at the low end of the dosing range, and increasing every 2 to 4 weeks until BP is controlled (<90th percentile), the maximal dose is reached, or adverse effects occur. If BP remains uncontrolled, a second agent can be added and dose can be titrated up as with the first agent. To balance the salt and water retention that occurs with many antihypertensive medications, a thiazide diuretic may be preferred as the second agent [1]. 
As is the case with many other pediatric chronic illnesses, clinicians caring for children with HTN face the dilemma of management strategies and medication utility and safety. While some concerns are related to the accuracy and reliability of BP measurements needed to confirm the diagnosis and initiate treatment, others are related to inherent physiologic, pharmacokinetic, pharmacodynamic, and daily lifestyle differences in children when compared to adults. In addition, the lack of large pediatric antihypertensive medication trials assessing dosing and safety often leads to extrapolation from adult data, raising the question of appropriate and safe prescribing. Lastly, given that antihypertensive agents are chronic medications, balancing the likelihood and risk of prolonged exposure adds to the complexity of initiating a child on these medications. For example, the use of certain classes of antihypertensives may affect bone mineral density (e.g., loop diuretics) [4], alter lipid (e.g., beta blockers and thiazide diuretics) and/or glucose metabolism (e.g., beta blockers) $[5,6]$, and have been correlated with an increased risk of malignancies (e.g., calcium channel blockers, angiotensin-converting enzyme inhibitors, angiotensin receptor blockers, and thiazide diuretics).

While clinicians should keep in mind the limitations to safely prescribing antihypertensive medications in children and use them only where indicated, it is also important to stress that untreated HTN has been associated with significant morbidities in children. These include but are not limited to left ventricular hypertrophy, increased markers of vascular stiffness, cognitive and learning disabilities, and faster progression of chronic kidney disease (CKD) in proteinuric hypertensive children [7-9]. However, unlike adult patients, the evidence for reduction of hard cardiovascular disease outcomes and mortality is lacking in children. Also, until now, we do not have enough evidence that treating HTN in childhood with antihypertensive medications will lead to reduction in hard clinical cardiovascular outcomes later in life; this remains to be answered in large, prospective pediatric studies.

The paradigm for pediatric antihypertensive trials has shifted in the last 20 years due to the Food and Drug Administration Modernization Act, which provided incentive for drug manufacturers to conduct clinical trials in pediatric patients. Thus, there was a surge of pediatric clinical trials by manufacturers looking to extend their patent; however, this has still left a huge gap for medications already off-patent that are still commonly prescribed in children. In this article, we aim to review the most common drug classes and pharmacologic agents used to manage HTN in pediatrics ( 0 to 18 years old) with an emphasis on safety (Table 1).
Angiotensin-converting enzyme inhibitors

\section{Efficacy}

Angiotensin-converting enzyme inhibitors (ACE-I) target the renin-angiotensin-aldosterone system (RAAS) and achieve their therapeutic effect by blocking the conversion of angiotensin I to angiotensin II, a potent vasoconstrictor [10]. Due to the inhibition of angiotensin II, ACE-I downregulate sympathetic activity, inhibit aldosterone secretion, and cause vasodilation at the efferent arteriole [10]. Furthermore, these medications inhibit the degradation of bradykinin, a vasodilator, which is also thought to contribute to the antihypertensive effects of ACE-I [11].

Being the most widely studied class, ACE-I are the most commonly prescribed antihypertensive class of medications in the pediatric patient population for both primary and secondary HTN [12]. The first study to trial use of enalapril in pediatrics included children 6 to 16 years old [13]. The authors reported a significant dose-response relationship across low, medium, and high dose groups in the initial 2-week phase $(p<0.001)$, as well as a statistically significant mean change in BP with placebo versus enalapril in the second 2-week phase $(p<0.003)$ [13]. The results of this trial led to FDA labeling of enalapril for pediatric patients. Interestingly, in the second phase the authors noted that younger patients $(\leq$ 12 years old or $\leq$ Tanner stage 3 ) tended to have more significant rebound in BP when assigned to placebo compared to older patients [13]. Lisinopril was subsequently approved with a similar study design the following year, also demonstrating a significant dose-response relationship in children 6 to 16 years $(p<0.001)$ [14]. Other FDA-approved ACE-I in pediatrics include fosinopril and benazepril, although both approvals were also based on limited trial data in the early 2000s [15]. Captopril however, despite having the most studies published across neonates to 18 years old remains "offlabel" for pediatric use.

The high prevalence of CKD as an etiology of secondary HTN in pediatrics and the reno-protective effects of ACE-I makes this drug class a desirable choice in this patient population. This likely results from the vasodilatory effects of ACE-I at the efferent arteriole, allowing for significant reduction of glomerular filtration pressure and decreased proteinuria [8]. The reno-protection is thought to be a class effect but some data postulates this may be more related to tighter BP control [16]. As reported in the ESCAPE trial, intensive BP control with ramipril aiming for targets below 50th percentile led to statistically significantly fewer patients experiencing decline in GFR by $50 \%$ or progression on end-stage kidney disease (ESKD) in intensive control group when compared to conventional control group $(p=0.02)$ [17]. In addition, patients experienced a decline in proteinuria from median 0.82 to $0.36 \mathrm{~g}$ protein per gram of creatinine $(p<0.001)$ [17]. It 
Table 1 Commonly prescribed oral antihypertensive agents in pediatrics

\begin{tabular}{|c|c|c|c|}
\hline Medication & Starting Dose & Common/Serious Side Effects & Comments \\
\hline \multicolumn{4}{|l|}{ Loop Diuretics } \\
\hline Furosemide & $\begin{array}{l}\text { Initial: } \\
0.5 \text { to } 2 \mathrm{mg} / \mathrm{kg} / \mathrm{DOSE} \text { ( } 20 \text { to } 80 \mathrm{mg} / \mathrm{DOSE} \text { ), } \\
\text { given once to four times daily } \\
\text { Maximum: } 6 \mathrm{mg} / \mathrm{kg} / \mathrm{DAY}(600 \mathrm{mg} / \mathrm{DAY} \text { ) }\end{array}$ & $\begin{array}{l}\text { Hypochloremic metabolic } \\
\text { alkalosis, hypokalemia, } \\
\text { hypomagnesemia, } \\
\text { hypovolemia, ototoxicity } \\
\text { (related to higher doses), } \\
\text { nephrolithiasis with long-term } \\
\text { use in premature infants }\end{array}$ & \\
\hline \multicolumn{4}{|l|}{ Thiazide Diuretics } \\
\hline Chlorothiazide & $\begin{array}{l}\text { Initial: } \\
10 \mathrm{mg} / \mathrm{kg} / \mathrm{DAY} \text {, divided once to twice daily } \\
\text { Maximum: } \\
20 \text { to } 40 \mathrm{mg} / \mathrm{kg} / \mathrm{DAY} \text { ( } 375 \mathrm{mg} \text { to } 2000 \mathrm{mg} / \mathrm{DAY} \text {, } \\
\text { age dependent) }\end{array}$ & \multirow{2}{*}{$\begin{array}{l}\text { Hypochloremic metabolic } \\
\text { alkalosis, hypokalemia, } \\
\text { hypercalcemia, } \\
\text { hyperglycemia, hypovolemia, } \\
\text { systemic lupus erythematosus } \\
\text { exacerbation, } \\
\text { photosensitivity, rash, } \\
\text { alopecia } \\
\text { Chlorothiazide only: } \\
\text { Hypercholesteremia and } \\
\text { hypertriglyceridemia }\end{array}$} & \multirow{2}{*}{$\begin{array}{c}\text { Use not } \\
\text { recommended in GFR } \\
<30 \mathrm{ml} / \text { minute } / 1.73 \mathrm{~m}^{2} \\
\text { contraindicated in } \\
\text { anuria }\end{array}$} \\
\hline Hydrochlorothiazide & $\begin{array}{l}\text { Initial: } \\
1 \text { to } 2 \mathrm{mg} / \mathrm{kg} / \mathrm{DAY} \text { ( } 37.5 \mathrm{mg} / \mathrm{DAY}) \text { divided once } \\
\text { to twice daily } \\
\text { Maximum: } \\
2 \text { to } 3 \mathrm{mg} / \mathrm{kg} / \mathrm{DAY}(50-100 \mathrm{mg} / \mathrm{DAY})\end{array}$ & & \\
\hline \multicolumn{4}{|c|}{ Potassium-sparing Diuretics } \\
\hline Spironolactone & $\begin{array}{l}\text { Initial: } \\
1 \mathrm{mg} / \mathrm{kg} / \mathrm{DAY}(25 \mathrm{mg} / \mathrm{DAY}) \text { divided once to } \\
\text { twice daily } \\
\text { Maximum: } \\
3.3 \mathrm{mg} / \mathrm{kg} / \mathrm{DAY} \text { ( } 100 \mathrm{mg} / \mathrm{DAY})\end{array}$ & hyperkalemia, gynecomastia & \\
\hline \multicolumn{4}{|l|}{ ACE Inhibitors } \\
\hline Captopril & $\begin{array}{l}\text { Neonates: } \\
\text { Initial: } \\
\text { Premature: } 0.01 \mathrm{mg} / \mathrm{kg} / \mathrm{DOSE} \text { given two to } \\
\text { three times daily } \\
\geq 7 \text { days: } 0.05-0.1 \mathrm{mg} / \mathrm{kg} / \mathrm{DOSE} \text { given once to } \\
\text { three times daily, maximum: } 0.5 \mathrm{mg} / \mathrm{kg} / \mathrm{dose} \\
\text { Infants/children: } \\
0.05-0.3 \mathrm{mg} / \mathrm{kg} / \mathrm{DOSE} \text { ( } 12.5 \text { to } 25 \mathrm{mg} / \mathrm{DOSE}) \\
\text { given once to four times daily } \\
\text { Maximum: } \\
6 \mathrm{mg} / \mathrm{kg} / \mathrm{DAY} \text { (150 mg/DAY) }\end{array}$ & $\begin{array}{l}\text { dry cough, hyperkalemia, } \\
\text { angioedema, elevated serum } \\
\text { creatinine, dysgeusia, } \\
\text { orthostatic hypotension }\end{array}$ & $\begin{array}{l}\text { Contraindicated in } \\
\text { pregnancy and in } \\
\text { patients with history } \\
\text { of angioedema or } \\
\text { bilateral renal artery } \\
\text { stenosis } \\
\text { Not approved for use } \\
\text { in neonates }\end{array}$ \\
\hline
\end{tabular}




\begin{tabular}{|c|c|c|c|}
\hline $\begin{array}{l}\text { Enalapril } \\
\text { FDA labeled for use in } \\
\geq 1 \text { month old }\end{array}$ & $\begin{array}{l}\text { Initial: } \\
0.08-0.1 \mathrm{mg} / \mathrm{kg} / \mathrm{DAY} \text { ( } 5 \mathrm{mg} / \mathrm{DAY}) \text { divided once } \\
\text { or twice daily } \\
\text { Maximum: } \\
0.6 \mathrm{mg} / \mathrm{kg} / \mathrm{DAY} \text { (40 mg/DAY) }\end{array}$ & & \\
\hline $\begin{array}{l}\text { Lisinopril } \\
\text { FDA labeled for use } \geq \\
6 \text { years old }\end{array}$ & $\begin{array}{l}\text { Initial: } \\
0.07 \mathrm{mg} / \mathrm{kg} / \mathrm{DAY} \text { (5 mg/DAY) given once daily } \\
\text { Maximum: } \\
0.6 \mathrm{mg} / \mathrm{kg} / \mathrm{DAY} \text { ( } 40 \mathrm{mg} / \mathrm{DAY} \text { ) }\end{array}$ & & \\
\hline \multicolumn{4}{|c|}{ Angiotensin Receptor Blockers } \\
\hline $\begin{array}{l}\text { Candesartan } \\
\text { FDA labeled for } \geq 1 \\
\text { year old }\end{array}$ & $\begin{array}{l}\frac{1 \text { to < } 6 \text { years old: }}{\text { Initial: }} \\
0.2 \mathrm{mg} / \mathrm{kg} / \mathrm{DAY} \text { ( } 4 \mathrm{mg} / \mathrm{DAY} \text { ) given once daily } \\
\text { Maximum: } \\
0.4 \mathrm{mg} / \mathrm{kg} / \mathrm{DAY} \text { (16 mg/DAY) } \\
6 \text { to } 16 \text { years old: } \\
\text { Initial: } \\
<50 \mathrm{~kg}-4 \mathrm{mg} / \mathrm{DAY}, \geq 50 \mathrm{~kg}: 8 \mathrm{mg} / \mathrm{DAY} \\
\text { Maximum: } \\
<50 \mathrm{~kg}: 16 \mathrm{mg} / \mathrm{DAY}, \geq 50 \mathrm{~kg}: 32 \mathrm{mg} / \mathrm{DAY}\end{array}$ & \multirow{3}{*}{$\begin{array}{c}\text { orthostatic hypotension, } \\
\text { headache, hyperkalemia, } \\
\text { angioedema, dry cough } \\
\text { (incidence higher in those } \\
\text { with cough on ACE-I) } \\
\text { candesartan only: } \\
\text { hypertriglyceridemia, } \\
\text { hyperuricemia, } \\
\text { hyperglycemia, depression }\end{array}$} & \multirow{3}{*}{$\begin{array}{l}\text { Contraindicated in } \\
\text { pregnancy and in } \\
\text { patients with history } \\
\text { of angioedema or } \\
\text { bilateral renal artery } \\
\text { stenosis } \\
\text { Use with GFR }<30 \\
\text { ml/minute } / 1.73 \mathrm{~m}^{2} \text { is } \\
\text { not recommended }\end{array}$} \\
\hline $\begin{array}{l}\text { Losartan } \\
\text { FDA labeled for use } \geq \\
6 \text { years old }\end{array}$ & $\begin{array}{l}\geq 6 \text { to < 17: years old: } \\
\text { Initial: } \\
0.7 \mathrm{mg} / \mathrm{kg} / \mathrm{DAY} \text { ( } 50 \mathrm{mg} / \mathrm{DAY} \text { ) given once daily } \\
\text { Maximum: } \\
1.4 \mathrm{mg} / \mathrm{kg} / \mathrm{DAY} \text { (100/DAY) } \\
\geq 17 \text { years old: } \\
\text { Initial: } \\
25-50 \mathrm{mg} \text { once daily } \\
\text { Maximum: } \\
150 \mathrm{mg} / \mathrm{DAY}\end{array}$ & & \\
\hline $\begin{array}{l}\text { Valsartan } \\
\text { FDA labeled for use } \geq \\
6 \text { years old }\end{array}$ & $\begin{array}{l}6 \text { to } 16 \text { years old: } \\
\text { Initial: } \\
1.3 \mathrm{mg} / \mathrm{kg} / \mathrm{DAY}(40 \mathrm{mg} / \mathrm{DAY}) \text { once daily } \\
\text { Maximum: } \\
2.7 \mathrm{mg} / \mathrm{kg} / \mathrm{DAY}(160 \mathrm{mg} / \mathrm{DAY})\end{array}$ & & \\
\hline
\end{tabular}




\begin{tabular}{|c|c|c|c|}
\hline Beta Blockers & \multicolumn{3}{|c|}{$\begin{array}{l}\text { Note: do not discontinue chronic beta blocker therapy abruptly to avoid rebound tachycardia } \\
\text { Use with caution in patients with history of bronchospasms } \\
\text { Can mask signs and symptoms of hypoglycemia and hypothyroidism }\end{array}$} \\
\hline Atenolol & $\begin{array}{l}\text { Initial: } \\
0.5 \text { to } 1 \mathrm{mg} / \mathrm{kg} / \mathrm{DAY}(25-50 \mathrm{mg} / \mathrm{DAY}) \text { divided } \\
\text { once or twice daily } \\
\text { Maximum: } \\
2 \mathrm{mg} / \mathrm{kg} / \text { day }(100 \mathrm{mg} / \text { day })\end{array}$ & \multirow{2}{*}{$\begin{array}{l}\text { Dizziness, syncope, } \\
\text { bradycardia, AV block, } \\
\text { vertigo, hyperkalemia, } \\
\text { gastrointestinal upset, } \\
\text { arthralgias }\end{array}$} & $\begin{array}{l}\text { Requires dose } \\
\text { adjustment in renal } \\
\text { dysfunction } \\
\text { Preferred for beta }{ }_{2}- \\
\text { selectivity in } \\
\text { asthmatics }\end{array}$ \\
\hline Carvedilol & $\begin{array}{l}\text { Initial: } \\
0.08 \mathrm{mg} / \mathrm{kg} / \mathrm{DOSE} \text { ( } 3.125 \mathrm{mg} / \mathrm{DOSE}) \text { given twice } \\
\text { daily } \\
\text { Maximum: } \\
1.5 \mathrm{mg} / \mathrm{kg} / \mathrm{DAY} \text { ( } 50 \mathrm{mg} / \mathrm{DAY})\end{array}$ & & $\begin{array}{l}\text { No manufacturer } \\
\text { dosing } \\
\text { recommendations in } \\
<18 \text { years old, dosing } \\
\text { taken from heart } \\
\text { failure } \\
\text { recommendations }\end{array}$ \\
\hline Labetalol & $\begin{array}{l}\text { Initial: } \\
1 \text { to } 3 \mathrm{mg} / \mathrm{kg} / \mathrm{DAY} \text { ( } 200 \mathrm{mg} / \mathrm{DAY} \text { ) divided twice } \\
\text { daily } \\
\text { Maximum: } \\
10 \text { to } 12 \mathrm{mg} / \mathrm{kg} / \mathrm{DAY} \text { ( } 1200 \mathrm{mg} / \mathrm{DAY})\end{array}$ & $\begin{array}{c}\text { Edema, orthostatic } \\
\text { hypotension, headache }\end{array}$ & \\
\hline $\begin{array}{l}\text { Metoprolol } \\
\text { (immediate-release) }\end{array}$ & $\begin{array}{l}\text { Initial: } \\
0.5-1 \mathrm{mg} / \mathrm{kg} / \mathrm{DOSE} \text { ( } 12.5 \text { to } 25 \mathrm{mg} / \mathrm{DOSE}) \text { given } \\
\text { twice daily } \\
\text { Maximum: } \\
6 \mathrm{mg} / \mathrm{kg} / \mathrm{DAY}(200 \mathrm{mg} / \mathrm{DAY})\end{array}$ & $\begin{array}{c}\text { Syncope, bradycardia, AV } \\
\text { block, cold extremities, } \\
\text { depression, vertigo, } \\
\text { nightmares, musculoskeletal } \\
\text { pain, tinnitus }\end{array}$ & $\begin{array}{l}\text { Extended release } \\
\text { (succinate } \\
\text { formulation) FDA } \\
\text { labeled in children } \geq 6 \\
\text { years old }\end{array}$ \\
\hline Propranolol & $\begin{array}{l}\text { Neonates } \\
\text { Initial: } \\
0.25 \text { to } 0.5 \mathrm{mg} / \mathrm{kg} / \mathrm{DOSE} \text {, given two to three } \\
\text { times daily } \\
\text { Maximum: } \\
4 \mathrm{mg} / \mathrm{kg} / \mathrm{DAY} \\
\text { Children/Adolescents } \\
\text { Initial: } 1 \text { to } 2 \mathrm{mg} / \mathrm{kg} / \mathrm{DAY} \text { divided two to three } \\
\text { time daily } \\
\text { Maximum: } \\
4 \mathrm{mg} / \mathrm{kg} / \mathrm{DAY} \text { ( } 640 \mathrm{mg} / \mathrm{DAY})\end{array}$ & & $\begin{array}{l}\text { Maximum dose } \\
\text { neonates: can go up } \\
\text { to } 5-10 \mathrm{mg} / \mathrm{kg} / \mathrm{day} \text { if } \\
\text { no bradycardia } \\
\text { present } \\
\\
\text { Maximum dose } \\
\text { children/ adolescents: } \\
\text { may go up to } 16 \\
\mathrm{mg} / \mathrm{kg} / \text { day ( } 640 \\
\mathrm{mg} / \mathrm{day})\end{array}$ \\
\hline
\end{tabular}




\begin{tabular}{|c|c|c|c|}
\hline \multicolumn{4}{|c|}{ Calcium Channel Blockers } \\
\hline $\begin{array}{l}\text { Amlodipine } \\
\text { FDA labeled for use in } \\
\geq 6 \text { years old }\end{array}$ & $\begin{array}{l}1 \text { to } 5 \text { years old: } \\
\text { Initial: } 0.05 \text { to } 0.1 \mathrm{mg} / \mathrm{kg} / \mathrm{DAY} \\
\text { Maximum: } 0.6 \mathrm{mg} / \mathrm{kg} / \mathrm{DAY}(5 \mathrm{mg} / \mathrm{DAY}) \\
6 \text { to } 17 \text { years old: } \\
\text { Initial: } 2.5 \text { to } 5 \mathrm{mg} \text { once daily } \\
\text { Maximum: } 10 \mathrm{mg} / \mathrm{DAY}\end{array}$ & \multirow{3}{*}{$\begin{array}{c}\text { Constipation, dizziness, } \\
\text { flushing, palpitations, } \\
\text { tachycardia, peripheral } \\
\text { edema }\end{array}$} & \\
\hline Isradipine & $\begin{array}{l}\text { Initial: } \\
0.05 \text { to } 0.1 \mathrm{mg} / \mathrm{kg} / \mathrm{DOSE}(2.5 \mathrm{mg} / \text { dose }) \text {, given } \\
\text { two to four times daily } \\
\text { Maximum: } \\
0.6 \mathrm{mg} / \mathrm{kg} / \mathrm{DAY}(10 \mathrm{mg} / \mathrm{DAY})\end{array}$ & & \\
\hline $\begin{array}{l}\text { Nifedipine (extended- } \\
\text { release) }\end{array}$ & $\begin{array}{l}\text { Initial: } \\
0.25 \text { to } 0.5 \mathrm{mg} / \mathrm{kg} / \mathrm{DAY} \text { ( } 30 \text { to } 60 \mathrm{mg} / \mathrm{DAY} \text { ), } \\
\text { divided once or twice daily } \\
\text { Maximum: } \\
3 \mathrm{mg} / \mathrm{kg} / \text { Day ( } 120 \mathrm{mg} / \mathrm{DAY} \text { ) }\end{array}$ & & $\begin{array}{l}\text { Cannot split or crush } \\
\text { extended release } \\
\text { tablets } \\
\text { May cause gingival } \\
\text { hyperplasia }\end{array}$ \\
\hline \multicolumn{4}{|l|}{ Vasodilators } \\
\hline Hydralazine & $\begin{array}{l}\text { Initial: } \\
0.75 \mathrm{mg} / \mathrm{kg} / \mathrm{DAY}(10 \mathrm{mg} / \mathrm{DOSE}) \text { divided three to } \\
\text { four times daily } \\
\text { Maximum: } \\
7.5 \mathrm{mg} / \mathrm{kg} / \mathrm{DAY}(200 \mathrm{mg} / \mathrm{DAY})\end{array}$ & $\begin{array}{l}\text { Orthostatic hypotension, } \\
\text { reflex tachycardia, dizziness, } \\
\text { peripheral edema, lupus-like } \\
\text { syndrome }\end{array}$ & $\begin{array}{l}\text { Dosing for use in } \\
\text { chronic hypertension } \\
\text { Requires dose } \\
\text { adjustment in renal } \\
\text { dysfunction }\end{array}$ \\
\hline
\end{tabular}

Dosing for non-FDA-approved antihypertensive medications added for guidance and were obtained from well-established drug references, AAP guidelines [1], and published clinical trials

should be noted however that over 36 months proteinuria gradually returned close to baseline levels. Subsequent studies have suggested the need for ACE-I and angiotensin receptor blocker (ARB) combination therapy to prevent aldosterone "escape" and proteinuria rebound [18, 19]; however, further trials are needed to corroborate this finding.

\section{Safety}

Despite being on the market for decades, data regarding safety of ACE-I in children remain limited. The benefits of prescribing ACE-I in the pediatric population should therefore be carefully weighed against the risks. The most commonly reported side effects with ACE-I in adults and children alike include hyperkalemia, rise in blood urea nitrogen and serum creatinine, and hypotension, with a higher incidence of hyperkalemia and elevated serum creatinine observed in neonates versus infants $[20,21]$. In addition, a lower incidence of dry cough has been reported in pediatrics when compared to adult patient population [22]. Other less common adverse effects include acute kidney injury and in rare but severe cases, angioedema. Secondary to pediatric patients' tendency towards dehydration in the setting of other common childhood illnesses, volume depletion and decreased blood flow to the kidneys only further perpetuate the risk of acute kidney injury [23]. While effective in controlling BP in renal artery stenosis [24], ACE-I are contraindicated in patients with bilateral renal artery stenosis and renal artery stenosis of a solitary kidney due to the profound risk of developing acute kidney injury and flash pulmonary edema [25-29]. The use of RAAS blockade, particularly in unilateral renal artery stenosis, however, remains controversial. This would require individualization of therapy in each clinical scenario after weighing risks versus benefits.

Given that the majority of studies were completed as "weightbanded" dose-response studies, there remains a concern regarding the most appropriate milligram per kilogram dose in pediatric 
patients. In addition, inherent physiologic and pharmacogenomic differences in pediatrics may further contribute to this concern. For example, higher intrinsic plasma renin activity and angiotensin II concentration in neonates increases risk of hypotension with the introduction of ACE-I and may require significant dose reductions as well as slower dose titrations [20]. Although personalizing therapy by following renin levels has been suggested $[30,31]$, this practice remains limited at this time. Additionally, several studies have reported attenuated response to ACE-I in adult African-American patient cohorts [32], and this finding has been corroborated in the pediatric population [33]. It should also be noted that ACE-I use is contraindicated in pregnancy due to serious risk of congenital malformations, particularly when exposure continues past the first trimester [34]. The most commonly reported fetopathies include hypocalvaria, oligohydramnios, pulmonary hypoplasia, acute kidney injury, and $\mathrm{CKD}$, in addition to other neurologic and cardiovascular complications in the fetus [35]. Thus, ACE-I should be prescribed with caution in adolescent females of child-bearing potential with emphasis on the need for close follow-up in this patient population.

A recently published population-based cohort study reported an increased risk of lung cancer with ACE-I when compared to ARBs [36]. Overall, there was a $14 \%$ increased risk of lung cancer reported in adult patients on ACE-I, with the association increasing with greater than 5 years of exposure to the drug class [36]. Possible explanations may include accumulation of bradykinin and substance $P$ in the lungs, which may have tumorigenic potential [37, 38]. It is unclear if the risk in adults is compounded secondary to other environmental exposures, and whether this risk can therefore be extrapolated to children. However, given the long-term exposure from initiation of therapy at a young age, this risk should be carefully considered. On the contrary, there is some data to suggest a protective effect of RAAS-inhibiting medications against cancer in carriers of particular ACE genotypes [39]. Thus, further studies are needed to assess the longterm safety of ACE-I prescribing in pediatrics.

\section{Angiotensin receptor blockers}

\section{Efficacy}

Similar to ACE-I, ARBs also target the RAAS; however, they work by directly antagonizing angiotensin II receptors. Since angiotensin II is generated by other pathways in addition to ACE, some have postulated that inhibiting the final step of this neurohormonal pathway with ARBs may provide more efficient blockade of the cardiovascular effects of angiotensin II with fewer side effects than ACE-I [40, 41]. On the contrary, with no action on ACE, ARBs do not alter bradykinin metabolism and the vasodilatory effects from elevated bradykinin levels seen with ACE-I may be lost when utilizing an ARB.
The clinical benefits of ARBs are similar to ACE-I, including effective BP reduction and decreased proteinuria [42], and they remain an acceptable initial pharmacologic option for monotherapy in managing HTN [1]. Current FDA-approved ARBs for use in pediatrics include losartan, valsartan, candesartan, and olmesartan, with the majority receiving approval for use in $>$ 6 years old. A study conducted by Flynn and colleagues was the first to evaluate efficacy and safety of valsartan in ages 1 to 5 years old [43]. Ninety patients with $\mathrm{SBP} \geq 95 \%$ were assigned 2:1:2 to a 2-week, double-blind, and dose-response phase (low, medium, and high dose), followed by an additional 2-week phase of valsartan versus placebo. All three dosing groups achieved a statistically significant reduction in mean seated SBP (low dose, $p<0.0001$; medium dose, $p=0.0002$; high dose, $p<0.0001$ ) but failed to demonstrate a linear dose-response between the three groups. A statistically significant reduction was also seen when the valsartan group was compared to placebo $(p=0.02)$. It should also be noted that the majority of patients in this study had HTN secondary to renal and urinary abnormalities $(80 \%)$, consistent with typical presentation of HTN in this age group. Despite this, however, assessment of proteinuria was not an endpoint in this study [43]. Wells et al. studied valsartan in children aged 6 to 16 years old with a similar study design and found dosedependent reductions in both sitting SBP and DBP across all three dosing groups $(p<0.0001)$ [44]. Furthermore, a study comparing valsartan and enalapril showed valsartan was non-inferior to enalapril in reducing mean seated SBP $(p<0.0001)$ [45].

Trachtman and colleagues demonstrated similar efficacy of candesartan in the CINCH trial, a 4-week, double-blinded, and placebo-controlled study of 240 patients aged 617 years old [46]. Statistically significant reductions of SBP were seen across low $(p=0.0074)$, medium $(p<0.0001)$, and high $(p<0.0001)$ dosing groups [46]. The $\mathrm{CINCH}$ investigators then published results of their parallel study assessing candesartan in 93 patients aged 1 to less than 6 years old [47]. They found a decline in SBP and DBP in all three dosing groups ( $p=0.01$ and $p=0.03$, respectively) at 4 weeks followup. Notably, the authors also found a statistically significant, dose-related, $57 \%$ median decline in proteinuria with candesartan at 4 weeks follow-up $(p=0.007)$. Similar findings have also been reported with losartan, the first ARB approved for use in pediatrics, with statistically significant reductions seen in both BP and proteinuria $[48,49]$. In the losartan study conducted by Shahinfar et al., the mean weight across all three dosing groups was $58.7 \pm 26.5 \mathrm{~kg}$ (range $17-152 \mathrm{~kg}$ ) and the mean age was $12 \pm 3.1$ years (range 5-16 years) [48]. Additionally, like many other pediatric antihypertensive studies, the authors used a "weight-banded" study design. For example, all patients $<50 \mathrm{~kg}$ in the medium dose group received $25 \mathrm{mg}$ of the study drug, whether their actual weight was $20 \mathrm{~kg}$ or $40 \mathrm{~kg}$. This raises the potential challenge in extrapolating results to infants and children as well as obese patients from studies where mean weight was closer to 
average adult weight, and mean age was closer to adolescence, when pharmacokinetics begin to closely reflect those of adults.

Olmesartan is the most recently studied and approved ARB for use in the pediatric patient population. A study assessing the palatability of various ARBs found that more children also preferred the taste of olmesartan over irbesartan, losartan, telmisartan, and valsartan [50]. The AESOP study group conducted a large trial for use of olmesartan in 302 patients aged 6 to 16 years old [51]. In addition to a typical dose-stratified study design, this trial was unique in that the investigators divided the patients into two cohorts, with cohort A consisting patients of various races (including blacks) and cohort $\mathrm{B}$ consisting of black patients only. Both cohorts demonstrated a statistically significant, dose-dependent reduction in seated SBP (cohort A, $p=$ 0.0008; cohort $\mathrm{B}, p=0.0032$ ) and seated DBP (cohort A, $p=$ 0.0026 ; cohort $\mathrm{B}, p=0.0125$ ) [51]. Interestingly, in both cohorts, patients switched to placebo demonstrated an increase in seated SBP compared to patients that remained on olmesartan; however, the increase in SBP was only statistically significant in cohort A $(p=0.0093)$ and not in cohort B (no $p$ value reported) [51]. Although the authors considered the sample size too small to assess statistical significance, this finding may also suggest that the diminished response to renin-angiotensin blocking agents seen in black adults may also be true in black children [52, 53].

Lastly, it would be worth noting that irbesartan failed to obtain FDA approval for pediatric HTN due to lack of efficacy.

\section{Safety}

One potential advantage of ARBs over other antihypertensives, particularly ACE-I, may be once daily dosing across all agents within the drug class, improving compliance in an already challenging patient population. All trials have reported ARBs as safe for use in pediatrics, with the most common adverse effects found to be headache, dizziness, and diarrhea [46-48, 51]. Other adverse effects expected with ARBs are closely related to those seen with ACE-I, given that both agents work on the RAAS. Similar to ACE-I, hyperkalemia, hypotension, and rise in blood urea nitrogen and serum creatinine are all potential side effects with ARBs. However, the incidence of dry cough and angioedema is significantly lower given the limited effect on bradykinin [54]. Patients transitioned to an ARB after developing dry cough or angioedema while on ACE-I must be counseled extensively on signs and symptoms should they recur. As seen with ACE-I, ARBs are also contraindicated in patients with bilateral renal artery stenosis given the risk of developing acute kidney injury, as well as in pregnancy for fetal abnormalities.

It should also be mentioned that there have been recalls of ARBs from the market secondary to nitrosamine contamination, a potential carcinogen. Valsartan was first found to have Nnitrosodimethylamine (NDMA), then N-nitroso-N-diethylamine (NDEA), followed by losartan with N-Nitroso-N-methyl-4- aminobutyric acid (NMBA); since then, this recall has been extended to other ARBs as well, namely irbesartan [55]. Although limited to medication lots that exceeded the "acceptable" daily nitrosamine exposure standard set forth by the FDA, this has led to fear of potential carcinogen exposure in providers and patients alike. The recalls only further highlight the need for closer regulation of the drug manufacturing and supply process [55].

\section{Aliskerin}

\section{Efficacy}

Of the newest drugs on the market and approved for pediatrics, aliskerin has shown mixed results. Aliskerin is a direct renin inhibitor that effectively decreases both renin and subsequent angiotensin activity [56]. Despite some promise in treating HTN and proteinuria in adults $[57,58]$, there remains a paucity of trials completed in the pediatric population.

A case report series of aliskerin use (dose range $1.7-4 \mathrm{mg} / \mathrm{kg}$ / day) in four patients (age 5-18 years old) with proteinuria refractory to other conventional therapies showed reduction in proteinuria in all patients, with adverse effects including hyperkalemia, abdominal pain, and symptomatic hypotension [59]. In addition, two patients developed renal failure; one patient experienced reversal in serum creatinine, while the other patient progressed to dialysis despite discontinuation of aliskerin [59].

A small pharmacokinetic study $(n=39)$ in pediatric hypertensive patients 6-17 years old showed a dose-dependent increase in aliskerin plasma concentrations (range $2-6 \mathrm{mg} / \mathrm{kg} /$ day) with headache, abdominal pain, and nausea as the most common, mild adverse effects [60]. The manufacturer of aliskerin (Tekturna, Novartis) then conducted a multi-center, randomized, and double-blind 8-week study in pediatric hypertensive patients aged 6-17 years old $(n=267)$ (NCT01150357). Patients were randomized to low, medium, or high doses, which ranged from 0.1 to $0.3 \mathrm{mg} / \mathrm{kg} /$ day $(6.25-25 \mathrm{mg}), 0.75$ to $1.8 \mathrm{mg} / \mathrm{kg} /$ day $(37.5-150 \mathrm{mg}$ ), and 3 to $7.5 \mathrm{mg} / \mathrm{kg} /$ day $(150-600 \mathrm{mg})$, respectively. A dose-related response was noted in phase 1 (week 0-4) with the largest change from baseline mean sitting SBP seen in high dose group of $-9.03 \pm 1.01$ versus $-5.54 \pm 0.78$ and $5.42 \pm 1.3 \mathrm{mmHg}$ in the low and medium groups, respectively. Adverse effects were similar to those reported in the adult population, with diarrhea and headache being the most common.

\section{Safety}

Despite these trials, the optimal dosing range in pediatrics for aliskerin is still unclear, with significant variability in trials and reports. It should also be noted that despite theoretical implications of using aliskerin in combination with ACE-I and ARBs to treat "renin and aldosterone escape" particularly in patients with proteinuria [61, 62], studies have reported a significant increase 
in the adverse effect profile, namely hyperkalemia, hypotension, and renal failure especially in patients with preexisting CKD [62-64]. The impact of use in pediatric CKD, a common finding in hypertensive pediatrics patients, is yet to be further evaluated. Lastly, aliskerin is contraindicated in patients less than 2 years of age. Given the limited evidence for treating HTN or proteinuria in children, more trials in the pediatric population to evaluate safety and efficacy are warranted.

\section{Diuretics}

\section{Efficacy}

There are three primary classes of diuretics that target various portions of the renal tubule. Loop diuretics are considered the most potent in action and work by inhibiting the sodium-potassium-chloride transport pump in the ascending loop of Henle [65]. This leads to a subsequent decrease in sodium and water reabsorption. Furosemide is most commonly used in neonates, children, and adolescents alike, with torsemide, bumetanide, and ethacrynic acid utilized less frequently in pediatrics. Thiazide diuretics, namely hydrochlorothiazide and chlorothiazide, also inhibit sodium reabsorption but target the distal renal tubules [66]. Although thiazide-like diuretics (chlorthalidone and metolazone) exhibit a similar mechanism of action, they are prescribed much less frequently in children. Lastly, potassium-sparing diuretics, including triamterene, amiloride, eplerenone, and primarily spironolactone, exert diuretic effect by antagonizing aldosterone in the distal tubule, causing increased sodium and water excretion into the urine while leaving behind potassium and hydrogen ions [67]. The overall resulting natriuretic effect and decrease in extracellular volume allows for reduction in BP.

Despite a lack of robust pediatric studies likely due to no financial incentives on non-patented drugs, the Clinical Practice Guideline for Screening and Management of High Blood Pressure in Children and Adolescents considers thiazide diuretics an acceptable initial pharmacologic option as monotherapy for managing HTN [1]. For long-term BP management, however, diuretics may be used in combination therapy as one would otherwise expect the RAAS and the sympathetic nervous system to compensate [68]. The only diuretic with pediatric-focused trials is eplerenone; however, the data was conflicting regarding its efficacy in treating HTN [69]. Diuretics are considered the cornerstone for treatment of monogenic forms of HTN, such as the use of triamterene and amiloride in glucocorticoid-remediable aldosteronism; the use of spironolactone, eplerenone, and amiloride in syndrome of apparent mineralocorticoid excess, triamterene and amiloride in Liddle syndrome; and the use of thiazide diuretics in Gordon syndrome [70]. In addition, diuretics may also be the preferred first-line or adjunctive agent in hypertensive patients with fluid overload or edematous conditions [71, 72].

\section{Safety}

There are several adverse effects related to diuretic therapy that should be considered. The most common adverse effects associated with diuretics are electrolyte disturbances, primarily hyponatremia, hypo-/hyperkalemia, and hypomagnesemia. Frequent urination secondary to diuretic therapy may be difficult for children and adolescents due to interruptions in daily routine as well as sleep throughout the night, and therefore, timing of doses should be tailored to the patient's routine. Lastly, patients particularly at higher risk for dehydration should be monitored carefully and frequently while on diuretics due to the risk of volume depletion [73].

As CKD is a common cause of pediatric HTN, it should be noted that thiazide diuretics, namely cholorthiazide and hydrochlorothiazide, are ineffective in augmenting diuresis in creatinine clearance $(\mathrm{CrCl})<30 \mathrm{~mL} / \mathrm{min} / 1.73 \mathrm{~m}^{2}$ [74]. Thiazide diuretics have also been found to contribute to systemic lupus exacerbations and parathyroid disease with prolonged use and can also lead to deranged metabolic profiles, particularly hypertriglyceridemia [75]. On the other hand, there may be a beneficial role for continuation of loop diuretics after dialysis initiation as lower rates of hospitalization, intradialytic hypotension, and lower interdialytic weight gain have been reported [76].

Loop diuretics have been identified as a primary risk factor for sensorineural hearing loss in preterm infants [77], albeit with some data showing limited statistical significance [78]. Also it should be noted that the use of loop diuretics as antihypertensive agents has been shown to correlate with poor mineral density and increased risk of fractures in adults [4, 79]. Potassium-sparing diuretics, particularly amiloride and spironolactone can increase risk of hyperkalemia, especially when used in combination with ACE-I and in the setting of renal insufficiency. Additionally, amiloride and spironolactone are notorious for the potential to cause gynecomastia in males [80], which may have a psychosocial impact in an adolescent and contribute to non-compliance; thus, eplerenone would be the preferred option in these patients. Lastly, Pederson et al. and Pottergard et al. recently reported an association between hydrochlorothiazide and risk of Merkel cell carcinoma, malignant adnexal skin tumors, and other nonmelanoma skin cancers, respectively [81-84]. Although these findings have not been corroborated by other authors [83], given that hydrochlorothiazide is a known photosensitizer, routine sun protection should be emphasized in patients. 


\section{Calcium channel blockers}

\section{Efficacy}

Among the two classes of CCBs, dihydropyridine CCBs primarily exhibit their effect as an antihypertensive by blocking the influx of extracellular calcium, which is needed for contraction of cardiac and vascular smooth muscles [85]. Inhibition of calcium flux at this step leads to peripheral arterial vasodilation, allowing for reduction in peripheral vascular resistance and BP [85]. Non-dihydropyridine CCBs (namely verapamil and diltiazem) exhibit negative chronotropic properties in addition to negative inotropy secondary to effects on the myocardium and AV node and are therefore typically reserved for patients requiring rate control [86]. For the continuity of discussing antihypertensives, this article will focus only on dihydropyridines.

The Clinical Practice Guideline for Screening and Management of High Blood Pressure in Children and Adolescents [1] includes long-acting CCBs as an acceptable first-line monotherapy agent, which primarily includes amlodipine and extended-release nifedipine. To date, amlodipine has the most literature and is the only FDA-approved CCB in pediatrics. Due to its prolonged half-life allowing for once daily dosing and a tablet form that allows for crushing and compounding of suspensions, amlodipine is the most often used CCB for maintenance therapy. In the largest pediatric study of 268 patients, a statistically significant dose-dependent SBP reduction was noted in the two dosing groups, with $-6.9 \mathrm{mmHg}$ in $2.5 \mathrm{mg}$ group versus placebo $(p=0.045)$ and $-8.7 \mathrm{mmHg}$ in $5 \mathrm{mg}$ group versus placebo $(p=0.005$ ) [87]. It should be noted that despite long half-life, younger patients may require twice daily amlodipine dosing for optimal BP control [88].

Although an immediate-release formulation of nifedipine is available and effective, it is primarily recommended for acute HTN. This dosage form, however, has fallen out of favor due to larger than desired reductions in BP, development of ventricular arrhythmias, and changes in neurologic status $[89,90]$. There are a limited number of studies with extended-release nifedipine and most are cross-over with other CCBs [91, 92].

CCBs may be superior in managing HTN in kidney transplant recipients when compared to other drug classes. In a systematic review and meta-analysis, CCBs were found to decrease BP, increase glomerular filtration rate, and reduce the risk for graft loss [93]. In a study of 24 post-renal transplant recipients, the authors reported similar efficacy in BP reduction with patients on extended-release nifedipine and amlodipine [91]. However, there was a $91.7 \%$ incidence of gingival hyperplasia in patients on nifedipine, with $90 \%$ reduction in symptoms with switch to amlodipine. Of note, all patients in this study were also receiving the older immunosuppressive drug cyclosporine also known to cause gingival hyperplasia, with similar trough levels reported between the two groups. Thus, it is difficult to decipher whether this side effect would be as prevalent on modern-day immunosuppressive regimens consisting of tacrolimus. In addition to limited availability of studies, the utility of extended-release nifedipine remains restricted in younger children as the extendedrelease tablet form cannot be crushed or split, often leaving amlodipine as the most viable option.

Felodipine's role in treating pediatric HTN remains controversial. An earlier study of 21 patients aged 6 to 17 years old, switched from nifedipine extended-release to felodipine extended-release, showed slightly better day time reduction in DBP $(p=0.05)$, but otherwise statistically similar findings between the two groups [92]. The dose-dependent response of felodipine extended-release was evaluated by Trachtman et al. in 128 patients aged 6 to 16 years old [94]. Their study showed reduction in DBP in the felodipine extended-release $5 \mathrm{mg}$ group when compared to placebo $(p<0.05)$, but no statistically significant changes in BP were noted in the $2.5 \mathrm{mg}$ and $10 \mathrm{mg}$ groups. Based on the results of this 2003 study, felodipine failed to obtain FDA approval labeling in pediatrics [94].

Isradipine continues to remain a viable option for acute reduction in BP [95]. Miyashita and colleagues showed a statistically significant reduction in SBP and DBP $(p<0.0001)$ with a majority of patients receiving a dose between $0.05 \mathrm{mg} / \mathrm{kg}$ and $0.1 \mathrm{mg} / \mathrm{kg}$ [96]. The highest reduction in mean arterial pressure (MAP) was noted in $<2$ years old, and thus, the authors recommended a lower starting dose in this age group [96]. Given its short half-life, however, use as maintenance therapy may be limited due to frequent dosing, but stability as an oral compounded suspension serves as advantageous in pediatrics.

\section{Safety}

The safety concerns and adverse effects of dihydropyridine CCBs appear primarily to be a class effect. The most common side effects include flushing, headache, dizziness, peripheral edema, tachycardia, nausea, vomiting, constipation, and gingival hyperplasia [86]. These are typically reversible upon discontinuation or dose reduction of the medication, making CCBs a fairly safe option in children. CCBs are metabolized by the liver via the CYP3A4 enzymatic pathway; thus, caution should be taken when prescribed concomitantly with other medications as they are highly prone to common but serious drug-drug interactions [85]. Initiation of CCBs should be done cautiously; toxicities with amlodipine have been reported at doses as low as $0.15-0.5 \mathrm{mg} / \mathrm{kg}$, particularly in children less than 6 years old $[97,98]$. Lastly, in light of conflicting data associating CCB use with cancer risk [99], it should be noted that recent adult data suggests an increased risk of pancreatic cancer in postmenopausal women [100]. The impact of these 
findings in the pediatric patient population however remains unclear.

One perceived advantage of CCBs may be their lack of nephrotoxicity, which makes this drug class an appealing choice as monotherapy or combination therapy in patients with kidney disease. However, it should also be noted that in adult patients with proteinuric renal diseases, studies have reported a lack of antiproteinuric effects of CCBs despite reduction in BP [101]. In addition, recent literature in pediatrics (abstract presented at the 2019 Pediatric Academic Societies Annual Meeting, Baltimore, MD) reported an increase in proteinuria in patients on dihydropyridine CCBs when compared to patients not on CCBs $(p=0.001)$ with no statistical difference in BP control (SBP, $p=0.420$; DBP, $p=0.146$ ) [102]. One proposed mechanism is that dihydropyridine CCBs block tubular protein reabsorption, leading to increased proteinuria [103]. Thus, this raises the question of the safe use of dihydropyridine CCBs as first-line therapy for HTN in children with CKD.

\section{Beta blockers}

\section{Efficacy}

In the most recent guidelines, beta blockers are not recommended for first-line management of HTN in pediatrics [1]. In patients unable to tolerate or still uncontrolled on ACE-I, ARBs, and/or CCBS, however, beta blockers may serve as a viable option. In addition, beta blockers may be considered for treating HTN in dialysis-dependent CKD patients and in children with migraine headaches [104, 105]. Despite being utilized for over 40 years, the beta blocker drug class has the least number of drugs FDA approved for use in pediatrics. Beta blockers work to reduce BP through both negative inotropic and chronotropic effects, thus effectively decreasing cardiac output [106]. The effect of each particular beta blocker is dependent upon specificity and selectivity to each betareceptor type; atenolol, bisoprolol, and metoprolol are very cardioselective and block only $\beta_{1}$ receptors, whereas others such as propranolol may antagonize both $\beta_{1}$ and $\beta_{2}$ receptors. In addition to blocking at $\beta_{1}$ and $\beta_{2}$ receptors, thirdgeneration beta blockers carvedilol and nebivolol also possess vasodilatory properties, with carvedilol exhibiting $\alpha 1$ blocking activity [107].

Metoprolol remains the only beta blocker FDA approved for use in pediatrics. Falkner et al. reported effectiveness of metoprolol in 16 adolescents aged 12-22 years old in reducing both mean $\operatorname{SBP}(p<0.001)$ and DBP $(p<0.001)$ with minimal side effects [108]. Patients were followed for 3 to 12 months and metoprolol dosing ranged from 100 to $200 \mathrm{mg}$ daily. A more recent trial of metoprolol extended-release studied 140 patients aged 6 to 16 years old randomized to four different groups comprising: placebo, $0.2 \mathrm{mg} / \mathrm{kg}, 1 \mathrm{mg} / \mathrm{kg}$, and $2 \mathrm{mg} / \mathrm{kg}$ [109]. A statistically significant decrease in BP was observed in both the $1 \mathrm{mg} / \mathrm{kg}(p=0.027)$ and $2 \mathrm{mg} / \mathrm{kg}(p=0.049)$ cohorts; however, this finding did not demonstrate a linear dose-response relationship [109]. It should also be noted that the majority of patients in this study were $>12$ years old and obese, with limited comorbidities reported; this may not reflect typical pediatric patients with HTN where the primary cause is often of renal origin [2]. In addition, the extended-release dosage form may have limited utility in children as it can only be split in half and not crushed.

Data for propranolol, atenolol, and carvedilol in children is primarily available for varying indications such as portal hypertension, congestive heart failure, migraines, and arrhythmias, suggesting efficacy with an acceptable safety profile [110-113]. Minimal studies, however, have examined their use in HTN. Although prescribed commonly, data for propranolol in hypertensive children is limited. A small cohort of nine patients receiving propranolol at a mean dose of $2.5 \mathrm{mg} / \mathrm{kg} /$ day demonstrated a mean reduction of SBP $(p<0.01)$ and DBP $(p<0.01)$ with reports of resting bradycardia $(n=1)$ and mild, selfresolving anorexia $(n=1)$ [114]. The mean dose in this study was fairly consistent with dosing utilized today in practice [115]. Atenolol has also shown to be effective in treating essential HTN in adults [116]; however, no studies can be found in children. Labetalol, with both $\alpha$ - and $\beta$-blocking effects, is typically used intravenously for hypertensive emergencies, but can be used in oral form to manage chronic HTN in a patient intolerant to other beta blockers [117].

A few studies were found in the literature combining a beta blocker with a thiazide diuretic in children. A combination study of propranolol/chlorthalidone was completed in 95 children with essential HTN aged 8 to 18 years [118]. A low-dose combined drug regimen with dietary changes was used, reporting a statistically significant decrease in both SBP and DBP up to 30 months [118]. A more recent trial was done to examine the safety and efficacy of a bisoprolol-hydrochlorothiazide combination in children versus placebo [119]. Ninety-four patients aged 6-17 years were randomized to receive either combination $(n=62)$ or placebo $(n=32)$. In the treatment group, bisoprolol doses were titrated from 2.5 to $10 \mathrm{mg}$ and hydrochlorothiazide dose remained at $6.25 \mathrm{mg}$. Although the authors noted a statistically significant reduction in mean sitting $\operatorname{SBP}(p<0.05)$ and DBP $(p<0.05)$, there was no statistical difference in the percentage of patients achieving target BP control (45\% treatment group versus $34 \%$ placebo, $p=\mathrm{NS}$ ) [119]. Based on these results, this drug combination did not attain FDA approval for use in pediatrics. 
Safety

There are several adverse effects related to beta blocker therapy that should be carefully considered in the pediatric patient population, most often related to extent of beta-selectivity of the drug prescribed [120]. Beta blockers with $\beta_{2}$ blockade activity should be cautiously prescribed in patients with history of asthma due to risk of bronchoconstriction from theoretical pulmonary crossreactivity [120]. Other common adverse effects include bradycardia, fatigue, and secondary to their lipophilicity, central nervous system effects including vivid dreams and hallucinations. As beta blockers effectively reduce cardiac output and attenuate heart rate, they can extensively limit ability for exercise; thus, use of these agents is not recommended in athletes [121, 122].

There are several reports suggesting worsened glycemic control with beta blockers. The two postulated mechanisms include inhibition of insulin release secondary to pancreatic beta-receptor blockade and reduced peripheral blood flow, preventing glucose from reaching skeletal muscles and tissues to facilitate its disposal [5]. In addition, there is concern that beta blockers may mask symptoms of hypoglycemia, primarily tachycardia, in diabetic patients [5]. In theory, these potential adverse effects can be minimized by utilizing $\beta_{1}$-selective blockers with $\alpha$ activity, such as carvedilol and nebivolol [123]. Compared to other antihypertensives, higher weight gain has been reported with beta blocker therapy, particularly with atenolol, metoprolol, and propranolol [124, 125]. Although the weight gain plateaus after the first few months, this should be taken into consideration when initiating patients on beta blockers [124, 125]. The impact of this observation in hypertensive children needs further investigation.

\section{Clonidine}

\section{Efficacy}

Clonidine stimulates the alpha ${ }_{2}$-adrenergic receptor, thus resulting in decreased sympathetic outflow leading to decreased peripheral vascular resistance, heart rate, and BP [126]. As recommended by the 2017 guidelines, use of clonidine to manage pediatric HTN should be reserved for patients unresponsive to two or more of the preferred agents [1]. It should be noted that the larger portion of current data in pediatrics comes from use of clonidine not only in hypertensive emergencies but also as an adjunct to sedation, analgesia, management of opioid withdrawal, and ADHD, often given at doses significantly lower than those used for HTN management $[127,128]$.
Safety

Given its direct effect on the brain stem, one primary concern with use of clonidine in pediatrics is oversedation or central nervous system depression, which may contribute to behavioral changes in an already vulnerable patient population [129]. Other notable potential adverse effects with clonidine include bradycardia and rebound tachycardia when abruptly discontinuing therapy. It is prudent therefore to taper the dose when discontinuing clonidine [130]. In addition, the dosage form of clonidine being prescribed in children must be carefully considered. While the transdermal patches may potentially increase compliance, they are only indicated in children $>6$ years old. Application of patches may also result in skin irritation and the potential for unexpected HTN if the patch falls off from the skin completely. Lastly, the practice of cutting transdermal patches to achieve pediatric dosing should be carefully evaluated. Zuppa and colleagues demonstrated a wider plasma concentration range, as well as a lower correlation between dose and plasma level, with cut versus whole patches [131]. The authors concluded that the rate and extent of absorption was less reliable with cut patches.

Methyldopa, also an $\alpha$-receptor agonist, has been prescribed in children as well despite limited clinical trials to support is use in the pediatric patient population.

\section{Direct vasodilators: hydralazine and minoxidil}

\section{Efficacy and safety}

Hydralazine is a direct vasodilator that decreases BP by causing relaxation of the arteriolar smooth muscle [132] and is typically utilized in pediatric patients with uncontrolled BP unresponsive to two or more of the preferred agents [1]. There are insufficient randomized controlled trials examining the effects of chronic oral hydralazine versus placebo on SBP, DBP, morbidity, and mortality while treating essential HTN in both adults and pediatrics [133]. Use of intravenous hydralazine in children in with acute HTN has been found safe and effective; however, the change in BP has been variable. In addition, primary adverse effects reported include rebound tachycardia, edema, and excessive BP reduction [134]. In addition, although the risk is higher in adults, hydralazine has the potential of inducing or exacerbating systemic lupus erythematosus in $5-10 \%$ of patients [135].

Similar to hydralazine, minoxidil also acts by directly vasodilating arteriolar smooth muscle and is also considered a last-line option [136]. A single-dose study of minoxidil in pediatric patients aged 2 to 18 years on a beta blocker and diuretic showed statistically significant post-dose reduction in SBP and DBP $(p<0.05)$ [137]. The authors noted a significant decline in SBP within the first hour of patients receiving doses $\geq 0.2 \mathrm{mg} / \mathrm{kg}(p<0.05)$, which was not seen in those 
receiving $<0.2 \mathrm{mg} / \mathrm{kg}$, suggesting a dose-related effect. No major adverse effects were reported other than two patients who had rebound HTN and two patients with rise in serum creatinine [137]. Conversely, Puri et al. studied chronic minoxidil therapy in 16 renal disease patients aged 1 to 16 years old with refractory HTN. Patients were followed for 2 to 77 months and doses ranged from 0.05 to $1.88 \mathrm{mg} / \mathrm{kg} /$ day [137]. A statistically significant decrease in mean BP was noted with minoxidil therapy $(p<0.001)$. The authors reported several adverse effects, primarily hypertrichosis in 14/16 patients, fluid retention, and congestive heart failure [137]. In addition, anorexia in neonates has also been reported in the literature with use of minoxidil [138].

Finally, prazosin and doxazosin, both $\alpha$-blockers, can also be used as part of the treatment regimens for specific causes of secondary HTN in pediatric patients, such as pheochromocytoma and paraganglioma $[139,140]$.

\section{Knowledge gaps and future directions}

The knowledge gaps that have been noted and suggestions for future directions are summarized below:

- While HTN in children is increasingly recognized, the lack of financial incentives for pharmaceutical companies and the numbers of participants needed for antihypertensive medication trials remains a major challenge in studies of both old and new antihypertensive medications. The majority of studies examining the efficacy and safety of new antihypertensive medications in children are industry sponsored. Innovative study designs that require smaller sample sizes and partnerships between pediatric research consortiums and pharmaceutical companies are needed.

- Comparative studies of antihypertensive medication classes for the pediatric population are largely lacking. The superiority of certain antihypertensive medication classes (by ethnicity or patient population) shown in adults remains to be extensively corroborated in pediatric patients.

- Neonatal HTN remains poorly understood and there is a pressing need for studies in this patient population to identify the "optimal" safe and efficacious antihypertensive medication class. The current practices of using ACE-I and other antihypertensive medication classes in premature infants with developing organs may potentially carry life-long consequences. Epidemiological and longitudinal cohort studies of those neonates are needed.

- The majority of ACE-I and ARB trials were completed in pediatric patients $\geq 6$ years old; thus, the effects of ACE-I/ ARBs in younger patients remains unexamined in clinical trials. Although ACE-I are considered drugs of choice for proteinuria, the phenomenon of rebound proteinuria and aldosterone escape needs further review and understanding in pediatric patients. The safety of combining different medication classes to target the RAAS need to be further studied in pediatric patients and cannot be endorsed with the current available evidence.

- "Weight-banded" studies with high mean weights and ages make it difficult to extrapolate this data to $\mathrm{mg} / \mathrm{kg}$ dosing in infants and children. Thus, more trials are needed following $\mathrm{mg} / \mathrm{kg}$ study design that is more reflective of clinically appropriate dosing strategies in pediatric patients.

- The emerging data on the carcinogenic potential of some antihypertensive medication classes (ACE-I, ARBs, thiazides, and CCBs) is concerning given the potential cumulative medication dose/year exposure in pediatric patients. Epidemiological and longitudinal cohort studies of adults exposed to antihypertensive medications in their childhood are needed.

- Recent studies looking at the role of the immune system in the development of HTN, and others aiming at manipulating the gut microbiota to lower BP (NCT02037295) may bring new approaches and medication classes that have a "broader" safety profile [141].

\section{Conclusion}

Due to a lack of large, well-designed pediatric safety and efficacy trials, limited understanding of pharmacokinetics in children, and unknown risk of life-long exposure to antihypertensive therapies, drug selection in treating pediatric HTN remains challenging. In recent years, significant progress has been made to study safety and efficacy of these agents in the pediatric population. Antihypertensive medications are generally safe to use in children, at least in the short term, but it is uncertain if their effects translate into improved long-term outcomes for children. Recent studies examining the role of the immune system and alteration of gut microbiota may allow for new approaches in managing HTN.

Funding Information Open Access funding provided by the Qatar National Library. The publication of this article was funded by the Qatar National Library.

\section{Compliance with ethical standards}

Conflict of interest The authors declare that they have no conflicts of interests.

Open Access This article is distributed under the terms of the Creative Commons Attribution 4.0 International License (http:// creativecommons.org/licenses/by/4.0/), which permits unrestricted use, distribution, and reproduction in any medium, provided you give appropriate credit to the original author(s) and the source, provide a link to the Creative Commons license, and indicate if changes were made. 


\section{References}

1. Flynn JT, Kaelber DC, Baker-Smith CM et al (2017) Subcommittee on Screening and Management of High Blood Pressure in Children. Clinical Practice Guideline for Screening and Management of High Blood Pressure in Children and Adolescents. Pediatrics 140(6). https://doi.org/10.1542/peds.2017-3035

2. McNiece KL, Poffenbarger TS, Turner JL, Franco KD, Sorof JM, Portman RJ (2007) Prevalence of hypertension and prehypertension among adolescents. J Pediatr 150:640-644 644.e641

3. Shatat IF, Brady TM (2018) Editorial: Pediatric hypertension: update. Front Pediatr 6:209

4. Lim LS, Fink HA, Kuskowski MA, Taylor BC, Schousboe JT, Ensrud KE, Osteoporotic Fractures in Men (MrOS) Study Group (2008) Loop diuretic use and increased rates of hip bone loss in older men: the Osteoporotic Fractures in Men Study. Arch Intern Med 168:735-740

5. Blackburn DF, Wilson TW (2006) Antihypertensive medications and blood sugar: theories and implications. Can J Cardiol 22:229-233

6. Deshmukh M, Lee HW, McFarlane SI, Whaley-Connell A (2008) Antihypertensive medications and their effects on lipid metabolism. Curr Diab Rep 8:214-220

7. ESCAPE Trial Group, Wühl E, Trivelli A, Picca S, Litwin M, Peco-Antic A, Zurowska A, Testa S, Jankauskiene A, Emre S, Caldas-Afonso A, Anarat A, Niaudet P, Mir S, Bakkaloglu A, Enke B, Montini G, Wingen AM, Sallay P, Jeck N, Berg U, Caliskan S, Wygoda S, Hohbach-Hohenfellner K, Dusek J, Urasinski T, Arbeiter K, Neuhaus T, Gellermann J, Drozdz D, Fischbach M, Möller K, Wigger M, Peruzzi L, Mehls O, Schaefer F (2009) Strict blood-pressure control and progression of renal failure in children. N Engl J Med 361:1639-1650

8. van den Belt SM, HJL H, Gracchi V, de Zeeuw D, Wühl E, Schaefer F, ESCAPE Trial Group (2018) Early proteinuria lowering by angiotensin-converting enzyme inhibition predicts renal survival in children with CKD. J Am Soc Nephrol 29:2225-2233

9. Lande MB, Kupferman JC (2019) Blood pressure and cognitive function in children and adolescents. Hypertension 73:532-540

10. Sinaiko AR (1994) Clinical pharmacology of converting enzyme inhibitors, calcium channel blockers and diuretics. J Hum Hypertens 8:389-394

11. Taddei S, Bortolotto L (2016) Unraveling the pivotal role of bradykinin in ACE inhibitor activity. Am J Cardiovasc Drugs 16:309-321

12. Yoon EY, Cohn L, Rocchini A, Kershaw D, Freed G, Ascione F, Clark S (2012) Antihypertensive prescribing patterns for adolescents with primary hypertension. Pediatrics 129:e1-e8

13. Wells T, Frame V, Soffer B, Shaw W, Zhang Z, Herrera P, Shahinfar S, Enalapril Pediatric Hypertension Collaborative Study Group (2002) A double-blind, placebo-controlled, doseresponse study of the effectiveness and safety of enalapril for children with hypertension. J Clin Pharmacol 42:870-880

14. Soffer B, Zhang Z, Miller K, Vogt BA, Shahinfar S (2003) A double-blind, placebo-controlled, dose-response study of the effectiveness and safety of lisinopril for children with hypertension. Am J Hypertens 16:795-800

15. Li JS, Berezny K, Kilaru R, Hazan L, Portman R, Hogg R, Jenkins RD, Kanani P, Cottrill CM, Mattoo TK, Zharkova L, Kozlova L, Weisman I, Deitchman D, Califf RM (2004) Is the extrapolated adult dose of fosinopril safe and effective in treating hypertensive children? Hypertension 44:289-293

16. Bakris GL (2008) Slowing nephropathy progression: focus on proteinuria reduction. Clin J Am Soc Nephrol 3(Suppl 1):S3-S10

17. Wühl E, Mehls O, Schaefer F, ESCAPE Trial Group (2004) Antihypertensive and antiproteinuric efficacy of ramipril in children with chronic renal failure. Kidney Int 66:768-776
18. Litwin M, Grenda R, Sladowska J, Antoniewicz J (2006) Add-on therapy with angiotensin II receptor 1 blocker in children with chronic kidney disease already treated with angiotensinconverting enzyme inhibitors. Pediatr Nephrol 21:1716-1722

19. Ruggenenti P, Cravedi P, Chianca A, Caruso M, Remuzzi G (2017) Achieving remission of proteinuria in childhood CKD. Pediatr Nephrol 32:321-330

20. Ku LC, Zimmerman K, Benjamin DK, Clark RH, Hornik CP, Smith PB, Best Pharmaceuticals for Children Act - Pediatric Trials Network Steering Committee (2017) Safety of enalapril in infants admitted to the neonatal intensive care unit. Pediatr Cardiol 38:155-161

21. Schoolwerth AC, Sica DA, Ballermann BJ, Wilcox CS, Council on the Kidney in Cardiovascular Disease and the Council for High Blood Pressure Research of the American Heart Association (2001) Renal considerations in angiotensin converting enzyme inhibitor therapy: a statement for healthcare professionals from the Council on the Kidney in Cardiovascular Disease and the Council for High Blood Pressure Research of the American Heart Association. Circulation 104:1985-1991

22. Baker-Smith CM, Benjamin DK, Califf RM, Murphy MD, Li JS, Smith PB (2010) Cough in pediatric patients receiving angiotensin-converting enzyme inhibitor therapy or angiotensin receptor blocker therapy in randomized controlled trials. Clin Pharmacol Ther 87:668-671

23. Terano C, Ishikura K, Miura M, Hamada R, Harada R, Sakai T, Hamasaki Y, Hataya H, Ando T, Honda M (2016) Incidence of and risk factors for severe acute kidney injury in children with heart failure treated with renin-angiotensin system inhibitors. Eur J Pediatr 175:631-637

24. Evans KL, Tuttle KR, Folt DA, Dawson T, Haller ST, Brewster PS, He W, Jamerson K, Dworkin LD, Cutlip DE, Murphy TP, D'Agostino RB, Henrich W, Cooper CJ (2014) Use of reninangiotensin inhibitors in people with renal artery stenosis. Clin J Am Soc Nephrol 9:1199-1206

25. Piecha G, Wiecek A, Januszewicz A (2012) Epidemiology and optimal management in patients with renal artery stenosis. J Nephrol 25:872-878

26. Hricik DE, Browning PJ, Kopelman R, Goorno WE, Madias NE, Dzau VJ (1983) Captopril-induced functional renal insufficiency in patients with bilateral renal-artery stenoses or renal-artery stenosis in a solitary kidney. N Engl J Med 308:373-376

27. Curtis JJ, Luke RG, Whelchel JD, Diethelm AG, Jones P, Dustan HP (1983) Inhibition of angiotensin-converting enzyme in renaltransplant recipients with hypertension. N Engl J Med 308:377-381

28. Takabatake T, Ohta H, Yamamoto Y, Ishida Y, Hara H, Ushiogi Y, Nakamura S, Hattori N (1987) Effect of angiotensin blockade and converting enzyme inhibition on renovascular hypertension: comparison between unilateral and bilateral renal artery stenosis. Angiology 38:434-439

29. Tillman DM, Adams FG, Gillen G, Morton JJ, Robertson JI (1987) Ramipril for hypertension secondary to renal artery stenosis. Changes in blood pressure, the renin-angiotensin system and total and divided renal function. Am J Cardiol 59:133D-142D

30. Laragh JH, Sealey JE (2011) The plasma renin test reveals the contribution of body sodium-volume content $(\mathrm{V})$ and reninangiotensin $(\mathrm{R})$ vasoconstriction to long-term blood pressure. Am J Hypertens 24:1164-1180

31. Flynn JT (2011) Management of hypertension in the young: role of antihypertensive medications. J Cardiovasc Pharmacol 58:111-120

32. Peck RN, Smart LR, Beier R, Liwa AC, Grosskurth H, Fitzgerald DW, Schmidt BM (2013) Difference in blood pressure response to ACE-inhibitor monotherapy between black and white adults with arterial hypertension: a meta-analysis of 13 clinical trials. BMC Nephrol 14:201

33. Li JS, Baker-Smith CM, Smith PB, Hasselblad V, Murphy MD, Califf RM, Benjamin DK (2008) Racial differences in blood 
pressure response to angiotensin-converting enzyme inhibitors in children: a meta-analysis. Clin Pharmacol Ther 84:315-319

34. Ratnapalan S, Koren G (2002) Taking ACE inhibitors during pregnancy. Is it safe? Can Fam Physician 48:1047-1049

35. Nadeem S, Hashmat S, Defreitas MJ, Westreich KD, Shatat IF, Selewski DT, Onder AM, Chiang M, Weaver DJ, Steinke J, Barcia J, Hernandez J, Hidalgo G, Ingraham SE, Abitbol CL, Pan C, Greenbaum LA (2015) Renin angiotensin system blocker Fetopathy: a Midwest pediatric nephrology consortium report. J Pediatr 167:881-885

36. Hicks BM, Filion KB, Yin H, Sakr L, Udell JA, Azoulay L (2018) Angiotensin converting enzyme inhibitors and risk of lung cancer: population based cohort study. BMJ 363:k4209

37. Brown NJ, Vaughan DE (1998) Angiotensin-converting enzyme inhibitors. Circulation 97:1411-1420

38. Kastner PR, Hall JE, Guyton AC (1984) Control of glomerular filtration rate: role of intrarenally formed angiotensin II. Am J Phys 246:F897-F906

39. van der Knaap R, Siemes C, Coebergh JW, van Duijn CM, Hofman A, Stricker BH (2008) Renin-angiotensin system inhibitors, angiotensin I-converting enzyme gene insertion/deletion polymorphism, and cancer: the Rotterdam Study. Cancer 112: 748-757

40. Roig E, Perez-Villa F, Morales M, Jiménez W, Orús J, Heras M, Sanz G (2000) Clinical implications of increased plasma angiotensin II despite ACE inhibitor therapy in patients with congestive heart failure. Eur Heart J 21:53-57

41. Burnier M (2001) Angiotensin II type 1 receptor blockers. Circulation 103:904-912

42. Seeman T, Pohl M, Misselwitz J, John U (2009) Angiotensin receptor blocker reduces proteinuria independently of blood pressure in children already treated with angiotensin-converting enzyme inhibitors. Kidney Blood Press Res 32:440-444

43. Flynn JT, Meyers KE, Neto JP, de Paula Meneses R, Zurowska A, Bagga A, Mattheyse L, Shi V, Gupte J, Solar-Yohay S, Han G, Pediatric Valsartan Study Group (2008) Efficacy and safety of the angiotensin receptor blocker valsartan in children with hypertension aged 1 to 5 years. Hypertension 52:222-228

44. Wells T, Blumer J, Meyers KE, Neto JP, Meneses R, Litwin M, Vande Walle J, Solar-Yohay S, Shi V, Han G, Valsartan Pediatric Hypertension Study Group (2011) Effectiveness and safety of valsartan in children aged 6 to 16 years with hypertension. J Clin Hypertens (Greenwich) 13:357-365

45. Schaefer F, Litwin M, Zachwieja J, Zurowska A, Turi S, Grosso A, Pezous N, Kadwa M (2011) Efficacy and safety of valsartan compared to enalapril in hypertensive children: a 12-week, randomized, double-blind, parallel-group study. J Hypertens 29: 2484-2490

46. Trachtman H, Hainer JW, Sugg J, Teng R, Sorof JM, Radcliffe J, Candesartan in Children with Hypertension $(\mathrm{CINCH})$ Investigators (2008) Efficacy, safety, and pharmacokinetics of candesartan cilexetil in hypertensive children aged 6 to 17 years. J Clin Hypertens (Greenwich) 10:743-750

47. Schaefer F, van de Walle J, Zurowska A, Gimpel C, van Hoeck K, Drozdz D, Montini G, Bagdasorova IV, Sorof J, Sugg J, Teng R, Hainer JW, Candesartan in Children with Hypertension Investigators (2010) Efficacy, safety and pharmacokinetics of candesartan cilexetil in hypertensive children from 1 to less than 6 years of age. J Hypertens 28:1083-1090

48. Shahinfar S, Cano F, Soffer BA, Ahmed T, Santoro EP, Zhang Z, Gleim G, Miller K, Vogt B, Blumer J, Briazgounov I (2005) A double-blind, dose-response study of losartan in hypertensive children. Am J Hypertens 18:183-190

49. Webb NJ, Lam C, Loeys T, Shahinfar S, Strehlau J, Wells TG, Santoro E, Manas D, Gleim GW (2010) Randomized, double- blind, controlled study of losartan in children with proteinuria. Clin J Am Soc Nephrol 5:417-424

50. Meier CM, Simonetti GD, Ghiglia S, Fossali E, Salice P, Limoni C, Bianchetti MG, CHIld Project (2007) Palatability of angiotensin II antagonists among nephropathic children. Br J Clin Pharmacol 63:628-631

51. Hazan L, Hernández Rodriguez OA, Bhorat AE, Miyazaki K, Tao B, Heyrman R, Assessment of Efficacy and Safety of Olmesartan in Pediatric Hypertension Study Group (2010) A double-blind, dose-response study of the efficacy and safety of olmesartan medoxomil in children and adolescents with hypertension. Hypertension 55:1323-1330

52. Ferdinand KC, Armani AM (2007) The management of hypertension in African Americans. Crit Pathw Cardiol 6:67-71

53. Menon S, Berezny KY, Kilaru R, Benjamin DK, Kay JD, Hazan L, Portman R, Hogg R, Deitchman D, Califf RM, Li JS (2006) Racial differences are seen in blood pressure response to fosinopril in hypertensive children. Am Heart J 152:394-399

54. Pylypchuk GB (1998) ACE inhibitor- versus angiotensin II blocker-induced cough and angioedema. Ann Pharmacother 32: 1060-1066

55. Byrd JB, Chertow GM, Bhalla V (2019) Hypertension hot potato - anatomy of the angiotensin-receptor blocker recalls. $\mathrm{N}$ Engl J Med 380:1589-1591

56. Ichihara A, Sakoda M, Kurauchi-Mito A, Narita T, Kinouchi K, Bokuda K, Itoh H (2010) New approaches to blockade of the renin-angiotensin-aldosterone system: characteristics and usefulness of the direct renin inhibitor aliskiren. J Pharmacol Sci 113: 296-300

57. Persson F, Rossing P, Reinhard H, Juhl T, Stehouwer CD, Schalkwijk C, Danser AH, Boomsma F, Frandsen E, Parving $\mathrm{HH}$ (2009) Renal effects of aliskiren compared with and in combination with irbesartan in patients with type 2 diabetes, hypertension, and albuminuria. Diabetes Care 32:1873-1879

58. Persson F, Lewis JB, Lewis EJ, Rossing P, Hollenberg NK, Parving HH (2011) Aliskiren in combination with losartan reduces albuminuria independent of baseline blood pressure in patients with type 2 diabetes and nephropathy. Clin J Am Soc Nephrol 6:1025-1031

59. Kelland EE, McAuley LM, Filler G (2011) Are we ready to use aliskiren in children? Pediatr Nephrol 26:473-477

60. Sullivan JE, Keefe D, Zhou Y, Satlin L, Fang H, Yan JH (2013) Pharmacokinetics, safety profile, and efficacy of aliskiren in pediatric patients with hypertension. Clin Pediatr (Phila) 52:599-607

61. Jacobsen P, Andersen S, Jensen BR, Parving HH (2003) Additive effect of ACE inhibition and angiotensin II receptor blockade in type I diabetic patients with diabetic nephropathy. J Am Soc Nephrol 14:992-999

62. Heerspink HJ, Persson F, Brenner BM, Chaturvedi N, Brunel P, McMurray JJ, Desai AS, Solomon SD, Pfeffer MA, Parving HH, de Zeeuw D (2016) Renal outcomes with aliskiren in patients with type 2 diabetes: a prespecified secondary analysis of the ALTITUDE randomised controlled trial. Lancet Diabetes Endocrinol 4:309-317

63. Harel Z, Gilbert C, Wald R, Bell C, Perl J, Juurlink D, Beyene J, Shah PS (2012) The effect of combination treatment with aliskiren and blockers of the renin-angiotensin system on hyperkalaemia and acute kidney injury: systematic review and meta-analysis. BMJ 344:e42

64. Mann JF, Schmieder RE, McQueen M, Dyal L, Schumacher H, Pogue J, Wang X, Maggioni A, Budaj A, Chaithiraphan S, Dickstein K, Keltai M, Metsärinne K, Oto A, Parkhomenko A, Piegas LS, Svendsen TL, Teo KK, Yusuf S, ONTARGET investigators (2008) Renal outcomes with telmisartan, ramipril, or both, in people at high vascular risk (the ONTARGET study): a 
multicentre, randomised, double-blind, controlled trial. Lancet 372:547-553

65. Eades SK, Christensen ML (1998) The clinical pharmacology of loop diuretics in the pediatric patient. Pediatr Nephrol 12:603-616

66. Khan NA, Campbell NR (2004) Thiazide diuretics in the management of hypertension. Can J Clin Pharmacol 11:e41-e44

67. Marrs JC (2010) Spironolactone management of resistant hypertension. Ann Pharmacother 44:1762-1769

68. Wald DS, Law M, Morris JK, Bestwick JP, Wald NJ (2009) Combination therapy versus monotherapy in reducing blood pressure: meta-analysis on 11,000 participants from 42 trials. Am J Med 122:290-300

69. Li JS, Flynn JT, Portman R, Davis I, Ogawa M, Shi H, Pressler ML (2010) The efficacy and safety of the novel aldosterone antagonist eplerenone in children with hypertension: a randomized, double-blind, dose-response study. J Pediatr 157:282-287

70. Ahn SY, Gupta C (2017) Genetic programming of hypertension. Front Pediatr 5:285

71. Grams ME, Estrella MM, Coresh J, Brower RG, Liu KD, National Heart, Lung, and Blood Institute Acute Respiratory Distress Syndrome Network (2011) Fluid balance, diuretic use, and mortality in acute kidney injury. Clin J Am Soc Nephrol 6:966-973

72. Kodati D, Yellu N (2017) Population pharmacokinetic modeling of furosemide in patients with hypertension and fluid overload conditions. Pharmacol Rep 69:492-496

73. Asplund C (2010) Treatment of hypertension in athletes: an evidence-based review. Phys Sportsmed 38:37-44

74. Aronoff GR (2007) Drug prescribing in renal failure: dosing guidelines for adults and children. American College of Physicians; [London: Royal Society of Medicine, distributor], Philadelphia, PA

75. Duarte JD, Cooper-DeHoff RM (2010) Mechanisms for blood pressure lowering and metabolic effects of thiazide and thiazidelike diuretics. Expert Rev Cardiovasc Ther 8:793-802

76. Sibbel S, Walker AG, Colson C, Tentori F, Brunelli SM, Flythe J (2019) Association of continuation of loop diuretics at hemodialysis initiation with clinical outcomes. Clin J Am Soc Nephrol 14:95-102

77. Borradori C, Fawer CL, Buclin T, Calame A (1997) Risk factors of sensorineural hearing loss in preterm infants. Biol Neonate 71:1-10

78. Wang LA, Smith PB, Laughon M, Goldberg RN, Ku LC, Zimmerman KO, Balevic S, Clark RH, Benjamin DK, Greenberg RG, Best Pharmaceuticals for Children Act Pediatric Trials Network Steering Committee (2018) Prolonged furosemide exposure and risk of abnormal newborn hearing screen in premature infants. Early Hum Dev 125:26-30

79. Ghosh M, Majumdar SR (2014) Antihypertensive medications, bone mineral density, and fractures: a review of old cardiac drugs that provides new insights into osteoporosis. Endocrine 46:397-405

80. Cuhaci N, Polat SB, Evranos B, Ersoy R, Cakir B (2014) Gynecomastia: clinical evaluation and management. Indian $\mathrm{J}$ Endocrinol Metab 18:150-158

81. Pedersen SA, Gaist D, Schmidt SAJ, Hölmich LR, Friis S, Pottegård A (2018) Hydrochlorothiazide use and risk of nonmelanoma skin cancer: a nationwide case-control study from Denmark. J Am Acad Dermatol 78:673-681 e679

82. Pottegård A, Pedersen SA, Schmidt SAJ, Hölmich LR, Friis S, Gaist D (2018) Association of hydrochlorothiazide use and risk of malignant melanoma. JAMA Intern Med 178:1120-1122

83. Gandini S, Palli D, Spadola G, Bendinelli B, Cocorocchio E, Stanganelli I, Miligi L, Masala G, Caini S (2018) Antihypertensive drugs and skin cancer risk: a review of the literature and meta-analysis. Crit Rev Oncol Hematol 122:1-9

84. Shin D, Lee ES, Kim J, Guerra L, Naik D, Prida X (2019) Association between the use of thiazide diuretics and the risk of skin cancers: a meta-analysis of observational studies. J Clin Med Res 11:247-255
85. Flynn JT, Pasko DA (2000) Calcium channel blockers: pharmacology and place in therapy of pediatric hypertension. Pediatr Nephrol 15:302-316

86. Sahney S (2006) A review of calcium channel antagonists in the treatment of pediatric hypertension. Paediatr Drugs 8:357-373

87. Flynn JT, Newburger JW, Daniels SR, Sanders SP, Portman RJ, Hogg RJ, Saul JP, PATH-1 Investigators (2004) A randomized, placebo-controlled trial of amlodipine in children with hypertension. J Pediatr 145:353-359

88. Flynn JT, Nahata MC, Mahan JD, Portman RJ, PATH-2 Investigators (2006) Population pharmacokinetics of amlodipine in hypertensive children and adolescents. J Clin Pharmacol 46:905-916

89. Egger DW, Deming DD, Hamada N, Perkin RM, Sahney S (2002) Evaluation of the safety of short-acting nifedipine in children with hypertension. Pediatr Nephrol 17:35-40

90. Castaneda MP, Walsh CA, Woroniecki RP, Del Rio M, Flynn JT (2005) Ventricular arrhythmia following short-acting nifedipine administration. Pediatr Nephrol 20:1000-1002

91. Silverstein DM, Palmer J, Baluarte HJ, Brass C, Conley SB, Polinsky MS (1999) Use of calcium-channel blockers in pediatric renal transplant recipients. Pediatr Transplant 3:288-292

92. Moncica I, Oh PI, ul Qamar I, Scolnik D, Arbus GS, Hebert D, Balfe JW, Koren G (1995) A crossover comparison of extended release felodipine with prolonged action nifedipine in hypertension. Arch Dis Child 73:154-156

93. Pisano AB, Davide, Mallamaci F, D’Arrigo G, Halimi J-M, Persu A, Wuerzner G, Sarafidis P, Watschinger B, Burnier M, Zoccali C (2019) Comparative effectiveness of different antihypertensive agents in kidney transplantation: a systematic review and metaanalysis. Nephrol Dial Transplant DOI: https://doi.org/10.1093/ ndt $/$ gfz092

94. Portman R, Restaino I, Matoo TK, Tou C, Klibaner M (2003) Clinical trial of extended-release felodipine in pediatric essential hypertension. Pediatr Nephrol 18:548-553

95. Flynn JT, Warnick SJ (2002) Isradipine treatment of hypertension in children: a single-center experience. Pediatr Nephrol 17:748-753

96. Miyashita Y, Peterson D, Rees JM, Flynn JT (2010) Isradipine for treatment of acute hypertension in hospitalized children and adolescents. J Clin Hypertens (Greenwich) 12:850-855

97. Benson BE, Spyker DA, Troutman WG, Watson WA, Bakhireva LN (2010) Amlodipine toxicity in children less than 6 years of age: a dose-response analysis using national poison data system data. J Emerg Med 39:186-193

98. Christensen MB, Petersen KM, Bøgevig S, Al-Gibouri S, Jimenez-Solem E, Dalhoff KP, Petersen TS, Andersen JT (2018) Outcomes following calcium channel blocker exposures reported to a poison information center. BMC Pharmacol Toxicol 19:78

99. Grimaldi-Bensouda L, Klungel O, Kurz X, de Groot MC, Maciel Afonso AS, de Bruin ML, Reynolds R, Rossignol M (2016) Calcium channel blockers and cancer: a risk analysis using the UK Clinical Practice Research Datalink (CPRD). BMJ Open 6:e009147

100. Wang Z, White DL, Hoogeveen R, Chen L, Whitsel EA, Richardson PA, Virani SS, Garcia JM, El-Serag HB, Jiao L (2018) Anti-hypertensive medication use, soluble receptor for glycation end products and risk of pancreatic cancer in the Women's Health Initiative Study. J Clin Med 7(8). https://doi. org/10.3390/jcm7080197

101. Kloke HJ, Branten AJ, Huysmans FT, Wetzels JF (1998) Antihypertensive treatment of patients with proteinuric renal diseases: risks or benefits of calcium channel blockers? Kidney Int 53:1559-1573

102. Richardson K, Weaver DJ, Ng DK, Carroll MK, Warady B, Furth S, Flynn JT (2019) Dihydropyridine calcium channel blocker therapy increases proteinuria among children with chronic kidney disease and high blood pressure. Pediatric Academic Societies Annual Meeting, Baltimore, MD 
103. Holdaas H, Hartmann A, Lien MG, Nilsen L, Jervell J, Fauchald P, Endresen L, Djøseland O, Berg KJ (1991) Contrasting effects of lisinopril and nifedipine on albuminuria and tubular transport functions in insulin dependent diabetics with nephropathy. J Intern Med 229:163-170

104. Hickman C, Lewis KS, Little R, Rastogi RG, Yonker M (2015) Prevention for pediatric and adolescent migraine. Headache 55: $1371-1381$

105. Georgianos PI, Agarwal R (2016) Pharmacotherapy of hypertension in chronic dialysis patients. Clin J Am Soc Nephrol 11:2062-2075

106. Kornbluth A, Frishman WH, Ackerman M (1987) Betaadrenergic blockade in children. Cardiol Clin 5:629-649

107. Yoshikawa T, Port JD, Asano K, Chidiak P, Bouvier M, Dutcher D, Roden RL, Minobe W, Tremmel KD, Bristow MR (1996) Cardiac adrenergic receptor effects of carvedilol. Eur Heart J 17(Suppl B):8-16

108. Falkner B, Lowenthal DT, Affrime MB (1982) The pharmacodynamic effectiveness of metoprolol in adolescent hypertension. Pediatr Pharmacol (New York) 2:49-55

109. Batisky DL, Sorof JM, Sugg J, Llewellyn M, Klibaner M, Hainer JW, Portman RJ, Falkner B, Toprol-XL Pediatric Hypertension Investigators (2007) Efficacy and safety of extended release metoprolol succinate in hypertensive children 6 to 16 years of age: a clinical trial experience. J Pediatr 150:134-139 139.e131

110. Samanta T, Purkait R, Sarkar M, Misra A, Ganguly S (2011) Effectiveness of beta blockers in primary prophylaxis of variceal bleeding in children with portal hypertension. Trop Gastroenterol 32:299-303

111. Mehta AV, Subrahmanyam AB, Anand R (1996) Long-term efficacy and safety of atenolol for supraventricular tachycardia in children. Pediatr Cardiol 17:231-236

112. Alabed S, Sabouni A, Al Dakhoul S, Bdaiwi Y, Frobel-Mercier AK (2016) Beta-blockers for congestive heart failure in children. Cochrane Database Syst Rev:CD007037

113. Merison K, Jacobs H (2016) Diagnosis and treatment of childhood migraine. Curr Treat Options Neurol 18:48

114. Griswold WR, McNeal R, Mendoza SA, Sellers BB, Higgins S (1978) Propranolol as an antihypertensive agent in children. Arch Dis Child 53:594-596

115. Kavey RE, Daniels SR, Flynn JT (2010) Management of high blood pressure in children and adolescents. Cardiol Clin 28:597-607

116. Frishman WH, Brobyn R, Brown RD, Johnson BF, Reeves RL, Wombolt DG (1994) Amlodipine versus atenolol in essential hypertension. Am J Cardiol 73:50A-54A

117. Ishisaka DY, Yonan CD, Housel BF (1991) Labetalol for treatment of hypertension in a child. Clin Pharm 10:500-501

118. Berenson GS, Shear CL, Chiang YK, Webber LS, Voors AW (1990) Combined low-dose medication and primary intervention over a 30-month period for sustained high blood pressure in childhood. Am J Med Sci 299:79-86

119. Sorof JM, Cargo P, Graepel J, Humphrey D, King E, Rolf C, Cunningham RJ (2002) Beta-blocker/thiazide combination for treatment of hypertensive children: a randomized double-blind, placebo-controlled trial. Pediatr Nephrol 17:345-350

120. Tafreshi MJ, Weinacker AB (1999) Beta-adrenergic-blocking agents in bronchospastic diseases: a therapeutic dilemma. Pharmacotherapy 19:974-978

121. Athletic participation by children and adolescents who have systemic hypertension (1997) American Academy of Pediatrics Committee on Sports Medicine and Fitness. Pediatrics 99:637-638

122. McCambridge TM, Benjamin HJ, Brenner JS, Cappetta CT, Demorest RA, Gregory AJ, Halstead M, Koutures CG, LaBella CR, Martin S, Rice SG, Council on Sports Medicine and Fitness (2010) Athletic participation by children and adolescents who have systemic hypertension. Pediatrics 125:1287-1294
123. McGill JB (2009) Reexamining misconceptions about $\beta$-blockers in patients with diabetes. Clin Diabetes 27:36-46

124. Wharton S, Raiber L, Serodio KJ, Lee J, Christensen RA (2018) Medications that cause weight gain and alternatives in Canada: a narrative review. Diabetes Metab Syndr Obes 11:427-438

125. Sharma AM, Pischon T, Hardt S, Kunz I, Luft FC (2001) Hypothesis: Beta-adrenergic receptor blockers and weight gain: a systematic analysis. Hypertension 37:250-254

126. Sica DA (2007) Centrally acting antihypertensive agents: an update. J Clin Hypertens (Greenwich) 9:399-405

127. Jain R, Segal S, Kollins SH, Khayrallah M (2011) Clonidine extended-release tablets for pediatric patients with attention-deficit/hyperactivity disorder. J Am Acad Child Adolesc Psychiatry 50:171-179

128. Honey BL, Benefield RJ, Miller JL, Johnson PN (2009) Alpha2receptor agonists for treatment and prevention of iatrogenic opioid abstinence syndrome in critically ill patients. Ann Pharmacother 43:1506-1511

129. Farooqi M, Seifert S, Kunkel S, Johnson M, Benson B (2009) Toxicity from a clonidine suspension. J Med Toxicol 5:130-133

130. Webster J, Koch HF (1996) Aspects of tolerability of centrally acting antihypertensive drugs. J Cardiovasc Pharmacol 27(Suppl 3):S49-S54

131. Zuppa AF, Tejani SM, Cullen EJ, Nadkarni VM (2004) Plasma concentrations following application of whole versus cut transdermal clonidine patches to critically ill children. J Pediatr Pharmacol Ther 9:43-48

132. Cohn JN, McInnes GT, Shepherd AM (2011) Direct-acting vasodilators. J Clin Hypertens (Greenwich) 13:690-692

133. Kandler MR, Mah GT, Tejani AM, Stabler SN, Salzwedel DM (2011) Hydralazine for essential hypertension. Cochrane Database Syst Rev 11:CD004934

134. Ostrye J, Hailpern SM, Jones J, Egan B, Chessman K, Shatat IF (2014) The efficacy and safety of intravenous hydralazine for the treatment of hypertension in the hospitalized child. Pediatr Nephrol 29:1403-1409

135. Arnaud L, Mertz P, Gavand PE, Martin T, Chasset F, Tebacher-Alt M, Lambert A, Muller C, Sibilia J, Lebrun-Vignes B, Salem JE (2019) Drug-induced systemic lupus: revisiting the ever-changing spectrum of the disease using the WHO pharmacovigilance database. Ann Rheum Dis 78:504-508

136. Sica DA (2004) Minoxidil: an underused vasodilator for resistant or severe hypertension. J Clin Hypertens (Greenwich) 6:283-287

137. Strife CF, Quinlan M, Waldo FB, Fryer CJ, Jackson EC, Welch TR, McEnery PT, West CD (1986) Minoxidil for control of acute blood pressure elevation in chronically hypertensive children. Pediatrics 78:861-865

138. Vesoulis ZA, Attarian SJ, Zeller B, Cole FS (2014) Minoxidilassociated anorexia in an infant with refractory hypertension. Pharmacotherapy 34:e341-e344

139. Bholah R, Bunchman TE (2017) Review of pediatric pheochromocytoma and paraganglioma. Front Pediatr 5:155

140. Randle RW, Balentine CJ, Pitt SC, Schneider DF, Sippel RS (2017) Selective versus non-selective $\alpha$-blockade prior to laparoscopic adrenalectomy for pheochromocytoma. Ann Surg Oncol 24:244-250

141. Al Khodor S, Reichert B, Shatat IF (2017) The microbiome and blood pressure: can microbes regulate our blood pressure? Front Pediatr 5: 138

Publisher's note Springer Nature remains neutral with regard to jurisdictional claims in published maps and institutional affiliations. 